\title{
From looking to reading: text-based conceptual art and typographic discourse
}

Article

Published Version

Blacksell, R. (2013) From looking to reading: text-based conceptual art and typographic discourse. Design Issues, 29 (2). pp. 60-81. ISSN 1531-4790 doi:

https://doi.org/10.1162/DESI_a_00210 Available at https://centaur.reading.ac.uk/31422/

It is advisable to refer to the publisher's version if you intend to cite from the work. See Guidance on citing.

To link to this article DOI: http://dx.doi.org/10.1162/DESI_a_00210

Publisher: MIT Press Journals

All outputs in CentAUR are protected by Intellectual Property Rights law, including copyright law. Copyright and IPR is retained by the creators or other copyright holders. Terms and conditions for use of this material are defined in the End User Agreement.

\section{www.reading.ac.uk/centaur}

\section{CentAUR}

Central Archive at the University of Reading

Reading's research outputs online 


\section{From Looking to Reading: Text-Based Conceptual Art and Typographic Discourse Ruth Blacksell}

I begin this discussion with a quote from Peter Osborne's book on Conceptual Art, where he notes how:

At its best, "Conceptual Art was never quite sure where the work was:" because it was never just in one place, or even one kind of place... Making this apparent, in opposition to the monistic materialism of Greenberg's late modernist criticism, was the most critically productive use of written language in the art of the 1960s... However, this does not mean that the visual dimension of linguistic inscription is irrelevant, even when it is the function of such inscription to negate the intrinsic significance of visual form. On the contrary, it is precisely its "unmarked" or neutral visual quality that performs the negation. In... many [artworks] of the period, this was achieved via design decisions associated with "publishing," rather than with "art."1

This quote is useful, not only because it introduces the emergence of text-based art works within this art historical period and situates them against the shifting critical discourse surrounding art at that time, but also because of the way in which it draws particular attention to typographic language and the activity of publishing as key factors in the ability of these works to, as Osborne puts it, "negate the intrinsic significance of visual form."

Retrospective critical accounts of Conceptual Art are numerous and include comprehensive discussion of the motivations behind the adoption of published typographic formats as a means of producing and disseminating art. However, what has surprised me in my own consideration of the works is how these accounts are often supported by poor quality or misleading reproductions, or a failure to cross-reference examples to each other. What this becomes then is a general failure to adequately demonstrate the precise nature and evolution of these works, either by failing to provide a full picture of their operation within this activity of publishing or through not giving a clear impression of the various 
different typographic configurations they employed, which would allow them to be understood collectively. Indeed, without these things, it can be hard to fathom exactly how these works can be understood as pieces of Conceptual Art and to appreciate the importance of their published typographic form to the achievement of this status.

As such, this discussion aims to present some key textbased artworks from this period and to describe more precisely how they operated typographically within the activity of publishing. This will not only add something to the art historical account of the works but will also serve to demonstrate their relevance to specific areas within typographic discourse, which are difficult to resolve within strict disciplinary boundaries.

\section{The Shift to Text in/as Art}

As noted by Osborne, these text-based works are situated against the backdrop of a very particular art historical period, which began in the mid-1960s and ended in the mid-1970s. Indeed, what is important in considering the works is that this period is generally characterized by a shift from the notion of art as an object toward the notion of art as an idea and, in particular, how this manifested itself in experiments with the ways in which the idea could be implemented conceptually through language rather than perceptually through vision.

The shift from object to idea is of course, as Osborne also states, connected to the collapse of Clement Greenberg's notion of medium-specific modernism and the emergence of a new art critical position, which moved away from the idea of the passive spectator looking at a pre-existing artwork toward the idea of an active spectator engaged somehow in the physical and/or conceptual creation of the work. So, in the case of these text works, what was presented-via typography and the publication of printed matter-was a context in which the spectator could conceivably encounter the artwork through the active process of reading rather than through any particular form of visual contemplation. In fact, this shift was specifically articulated by the artist Robert Smithson in his 1967 press release, "Language to be Looked At and/or Things to be Read" and by Terry Atkinson in his 1968 essay, "Concerning the Article: 'The Dematerialization of Art."'2

It is also relevant that what is described as "the turn to

Robert Smithson, "Language to be Looked At and/or Things to be Read," press release written for the first of four "Language" shows at Dwan Gallery in New York between 1967 and 1970 (1967); Atkinson, "Concerning the Article: 'The Dematerialisation of Art'" (1968).

3 Peter Osborne, "Conceptual Art and/ as Philosophy," in Rewriting Conceptual Art, ed. John Bird and Michael Newman (London: Reaktion Books Ltd., 1999). language" in the art of this period connects these text works to the philosophical shift through structuralism and semiotics, as described in Osborne's essay, "Conceptual Art and/as Philosophy." ${ }^{\prime 3}$ And it is interesting that accounts of this shift refer to much earlier text-based experiments in literature and poetry including, for instance, Laurence Sterne's novel Tristram Shandy, which was published in the mid-18th century and Stéphane Mallarmé's poem 


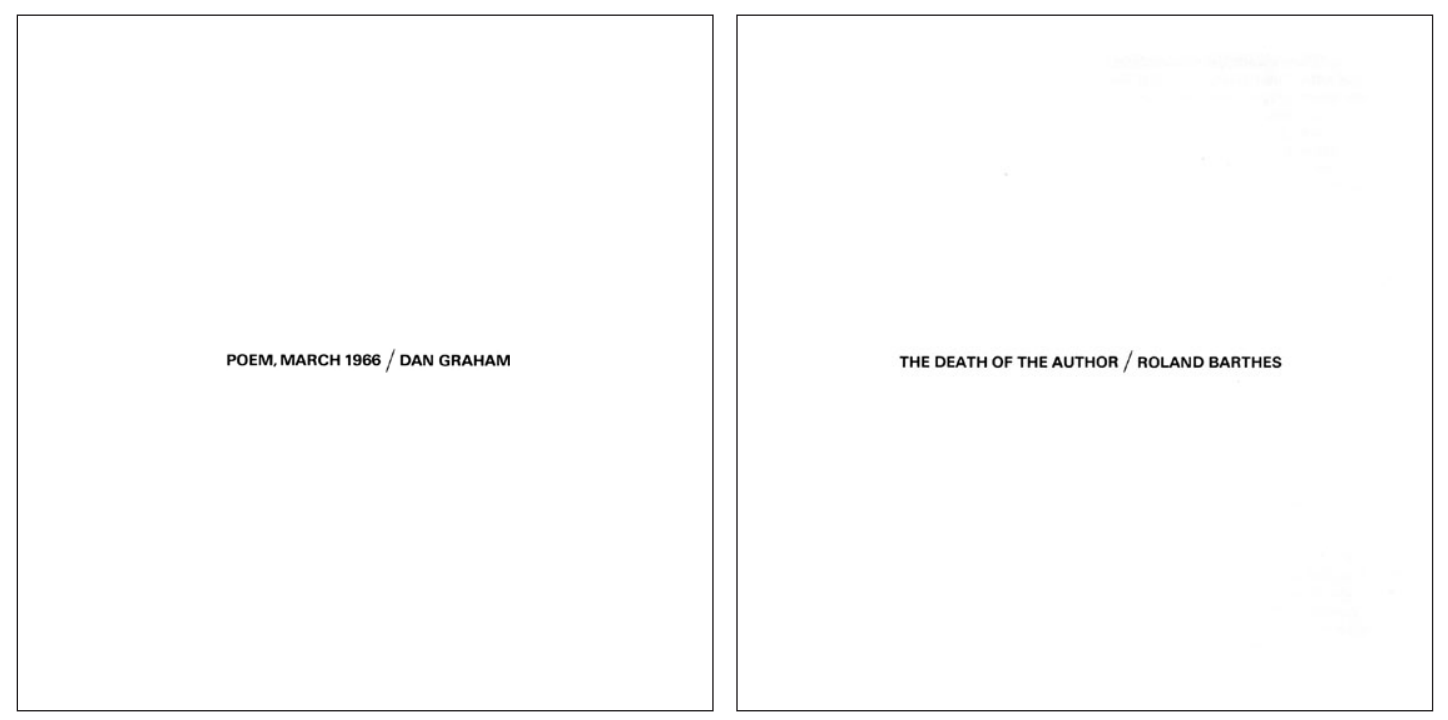

Figure 1

Two identical booklets included in Aspen, 5+6, Fall \& Winter (1967-68). Courtesy Alun Rowlands: private collection.

(left) Dan Graham, "Poem, March 1966."

(right) Roland Barthes, "The Death of the Author."
4 The Life and Opinions of Tristram Shandy, Gentleman was originally published in nine small separate volumes between 1759 and 1767; Un Coup de Dés Jamais n'Abolira le Hazard [A Roll of the Dice Will Never Abolish Chance], was first published as a 20-page poem in 1897.

5 See Barthes's essay, "The Death of the Author" (1967) and his distinction in S/Z between the "Readerly text," which is transitive, acting purely as a conveyor of meaning, and the "Writerly text," which is intransitive, aiming not to take the reader beyond but to draw attention to the activity of writing itself (1973).
A Roll of the Dice, which was published in the late 19th century, as well as French experimental writings of the 1950s from those like Michel Butor and Alain Robbe-Grillet, and the work of postWar American poets like Jackson MacLow and John Ashbery. ${ }^{4}$

Indeed, what these earlier experiments demonstrate, alongside the style of their writing, is the use of specific textual arrangements and page layout to disrupt what has subsequently been described as a "readerly" immersion in the text. This is an idea that, by the late 1960s, had been articulated through the theoretical writings of Roland Barthes through, for example, his depictions of "the death of the author" and the "writerly text."

So, in relation to the turn to language and text in the art of this period, it is worth noting that "The Death of the Author" was first published in 1967 in a printed booklet within the art magazine Aspen alongside another identical booklet that contained an important typographic work by the artist Dan Graham: "Poem, March 1966" (see Figure 1). As with Barthes's essay, this work by Graham is discussed in relation to a conceptual shift away from the idea of artistic authorship and the autonomous work through the way in which it is typographically constructed, not by the artist but via an editor's response to questions about a document's editorial and design specification (see Figure 2).

What is therefore essential with regard to these text-based Conceptual artworks is to see how they, in fact, emerged out of the intersecting of a number of historical and theoretical factors. These include the aforementioned philosophical territory and the obvious art historical lineage back to the nomination and staging of Duchamp's Readymades, but also incorporate other contextual features surrounding the visual arts at that time, such as the breakdown of the critical discourse of medium-specific modernism and links to experimental poetry and literature. What is more, this also 


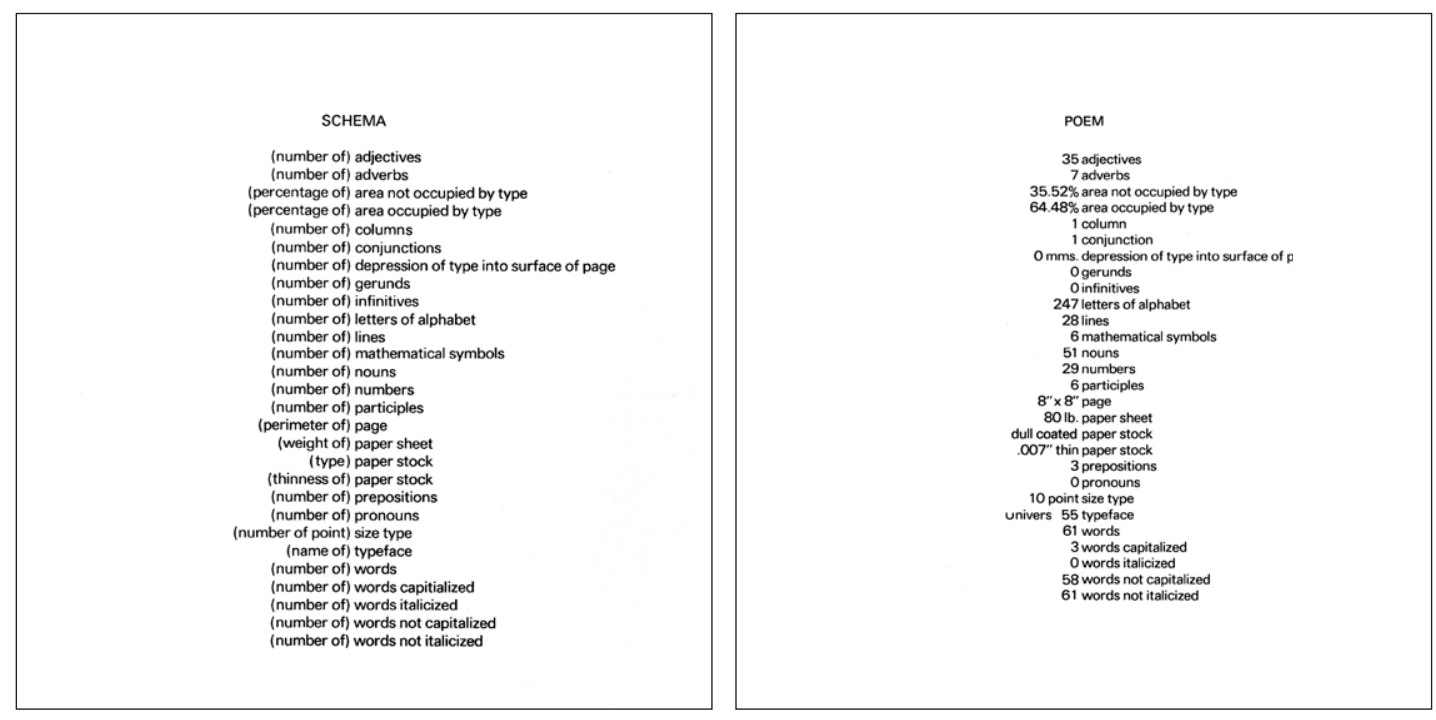

Figure 2

Dan Graham, "Poem, March 1966" as reproduced on consecutive pages of a booklet in Aspen, 5+6, Fall \& Winter (1967-68). Courtesy the artist, Lisson Gallery and Alun Rowlands: private collection.

(left) The piece begins with a set of questions (entitled "Schema") about the editorial and design specification of the poem's host publication and an instruction from Graham that the list of questions is to be "set in its final form by the editor of the publication where it is to appear." Graham also states that this activity should happen in various magazines to create a series, or "set," of "individual poems."

(right) The final "Poem" (the answers to the questions posed by the Schema) thus appears as a unique text-piece each time it is reproduced, being specifically derived from the individual editorial and design specification of its host publication.

6 Dan Graham and Nicolás Guagnini, "A Conversation Between Dan Graham and Nicolás Guagnini: New York, New York, 14 May 2006," in Dan Graham: Beyond, ed. Bennett Simpson and Chrissie lles (Los Angeles and Massachusetts: The Museum of Contemporary Art, Los Angeles and The MIT Press, 2009), 278. Graham had earlier described how he wanted to connect the serial logic of Minimalism with this new type of sociological journalism: "Esquire magazine was publishing sociological exposes like extends to the particular social and economic climate at that time in the 1960s, which had provided new possibilities for the positioning of art within published contexts, ranging from short-run officeprinted documents to mass-circulation illustrated magazines.

Indeed, what these new publishing contexts specifically helped to create was a different kind of location for art, as well as a different kind of audience-one that would be receptive (whether knowingly or not) to the positioning of works within these kinds of printed matter. As Dan Graham put it:

I didn't go to art school or college, but I read a lot of magazines like Esquire ... Not to be academic about it but I think the mid-60s was magazine culture. I really liked Esquire, which had writing and also photographs by famous photographers, often about the suburbs. ${ }^{6}$

\section{The Published Text as Conceptual Artwork}

Within their own niche, examples of text-based Conceptual Art appropriate a diverse array of typographic and publishing genres. However, rather than attempting to present a survey of "types," my intention is to consider how it was the act of positioning these works within this context of publishing that specifically allowed them to undermine traditional ideas of form, authorship, and the "Institution," which had dominated pre-1960s art.

The works I present here are therefore not those involving one-off painted or stenciled texts, as for example produced by artists like On Kawara or Ed Ruscha, which are in some ways easier to describe and exhibit through conventional author/objectbased criteria. Instead, I specifically focus on those works that were typeset and distributed through the channel of mainstream, print-based, publishing and, as such, can be identified as much with the activity of publishing as with their particular material form as printed matter. 


\section{Homes for America}

Early 20th-Century Possessable House
to the Quasi-Discrete to the Quasid
Cell of ' 66

Cell of ' 66
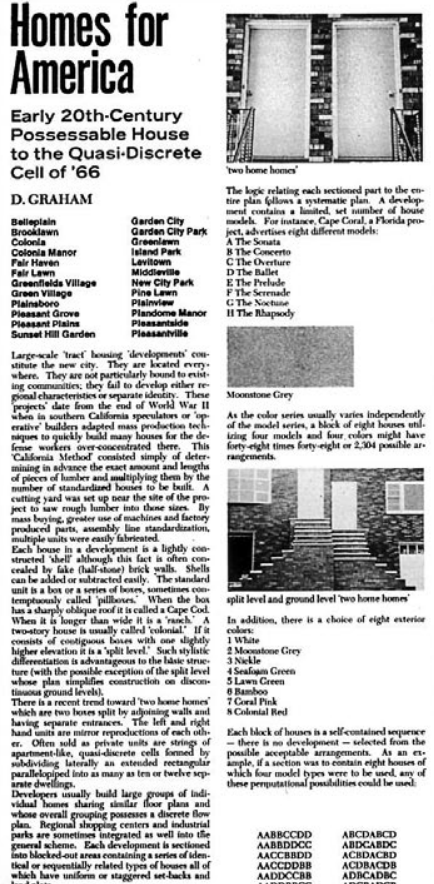

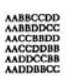

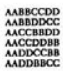

Figure 3

Dan Graham, "Homes for America," original paste up for Arts Magazine (1966). Courtesy the artist and Lisson Gallery.
David Riesman's 'The Lonely Crowd.

They used photographers in the school of Walker Evans ... [and] were showing vernacular workers' housing, suburban housing ... I wanted to show that Minimal was related to a real social situation that could be documented." (Dan Graham interviewed by Mike Metz in Two Way Mirror Power: Selected Writings by Dan Graham on his Art, ed., Alexander Alberro (Massachusetts and London: The MIT Press, 1999 [1994]), 185.

7 Various sources record the involvement of artists at that time with the editorship and design of both arts and mainstream magazines: See for example James Meyer, "The Mirror of Fashion: Dale McConathy and the Neo-Avant Garde," in Artforum, vol. XXXIX, no. 9 (2001): 134-38.
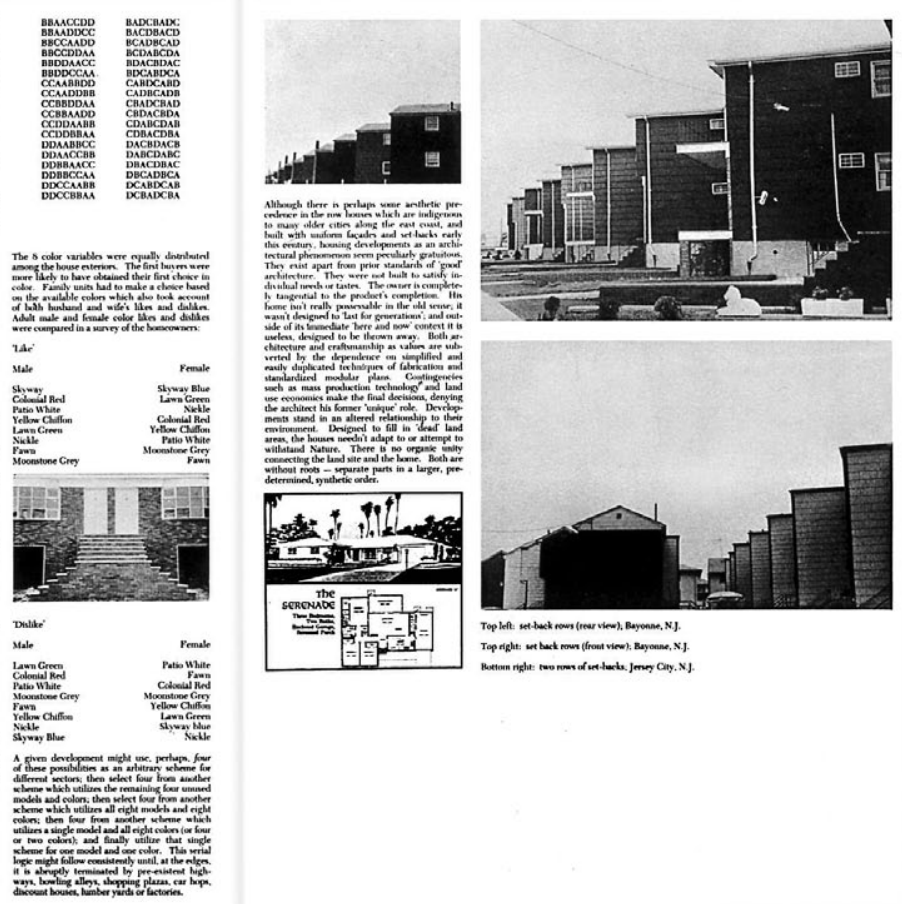

Take, for example, the work "Homes for America" by Dan Graham (see Figure 3), which is held up as one of the seminal pieces of text-based Conceptual Art: The usual account of this work is that it began as a proposal for an illustrated magazine article, with the content and arrangement of the text and images referring back to the serial logic of Minimalist Art via a descriptive, reportage-style account of suburban tract housing in a New Jersey suburb (see Figure 4). In fact, from its outset, Graham had in mind an intention to place this work within a mainstream published context through his production of a pasted-up page layout intended for submission to a magazine editor.

As the story goes, Graham was initially thinking of a masscirculation magazine like Esquire but, possibly because his friend Robert Smithson was a contributing editor at Arts Magazine, he prepared and presented it instead to that publication. ${ }^{7}$ And it was at this point - the point at which it was accepted by Arts Magazinethat the work made its shift from a static (conventionally objectlike) paste-up (see Figure 3) into the active context of publishing, whereby the editors changed the layout to follow the magazine's house style and replaced some of Graham's photographs with alternative imagery (see Figure 5).

So the operation of this work as a piece of Conceptual Art lies in this shift away from the autonomous art object; away from the hand of the author; away from the Institution; and into the work existing within the activity of mainstream publishing via its 


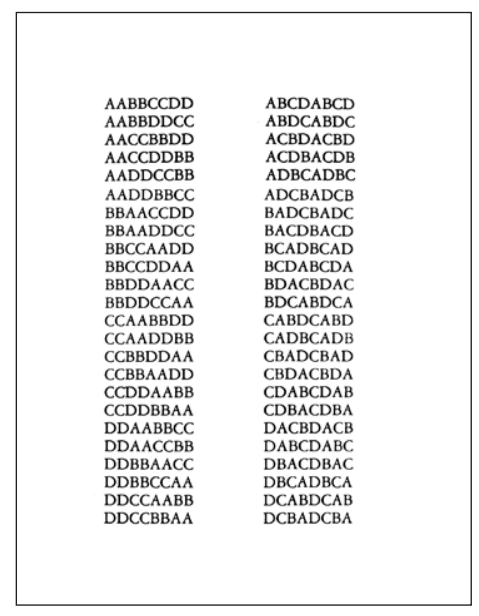

Figure 4

Dan Graham, "Homes for America," text and image details. Courtesy the artist and Lisson Gallery.

\section{Figure 5}

Dan Graham, "Homes for America" as reproduced in Arts Magazine, vol. 41, no. 3, (December 1966 - January 1967). Courtesy the artist and Lisson Gallery.
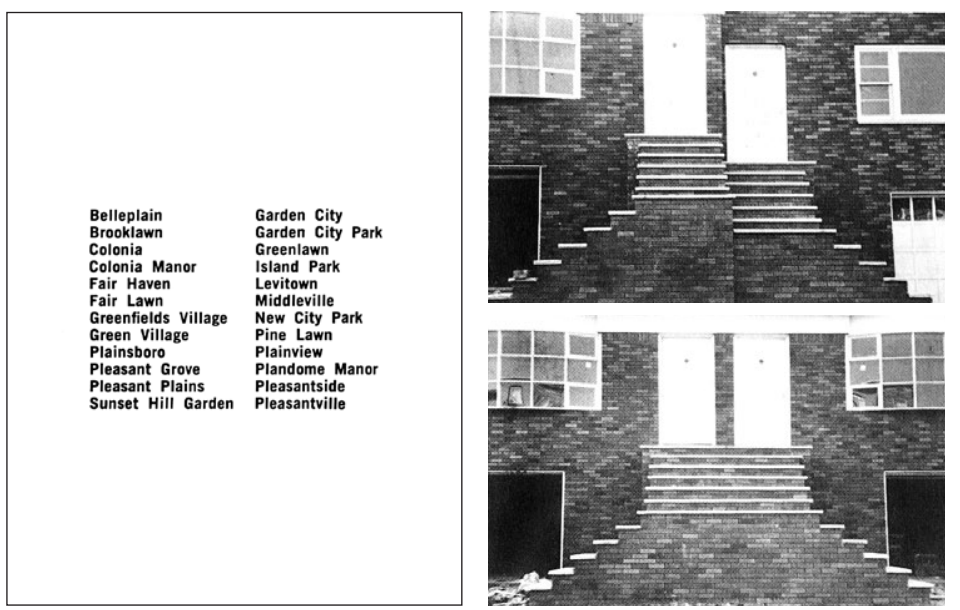

editorial alteration and reproduction-and, importantly, through its subsequent re-formulation in later published versions (see Figures 6 and 7).

As I have said though, it can be hard to get your head around this properly when faced with the available reproductions of "Homes for America," which fail to give the full picture of this evolution since they usually depict just one of these versions of the work. What is more, whichever the version depicted, the individual reproductions all appear captioned with the same overall title- "Homes for America" - without sufficient visual explanation of their individual position as one of the various stages in this potentially on-going progression.
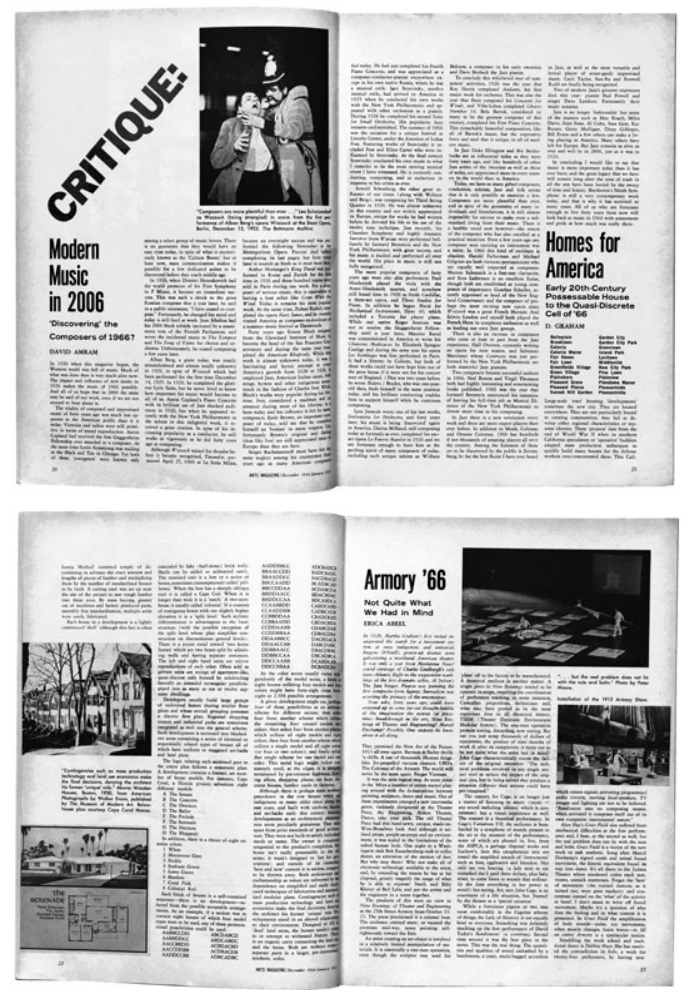


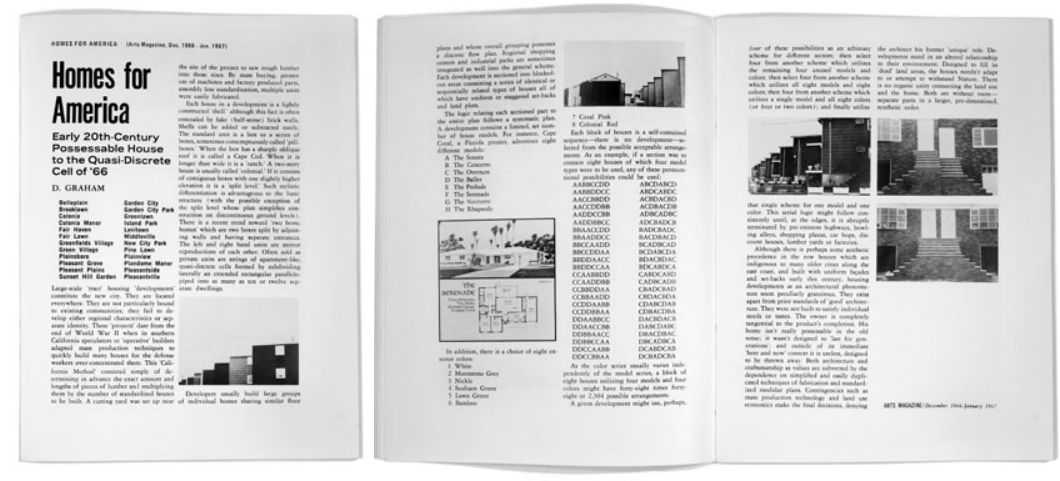

Figure 6

Dan Graham, "Homes for America," revised version of article layout as reproduced in Dan Graham, a booklet produced by Lisson Publications: London and Koenig Publishing: Cologne \& New York (1972). Courtesy the artist and Lisson Gallery.

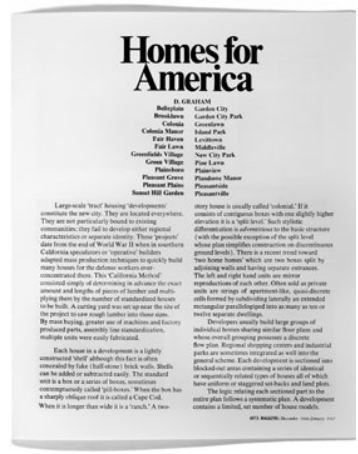

Figure 7

Dan Graham, "Homes for America," revised version of article layout as reproduced in For Publication, Otis Art Institute of Los Angeles County (1975). Reprinted in 1991, by Marian Goodman Gallery: New York . Courtesy the artist and Lisson Gallery.
8 See, for example, Graham's essay "My Works for Magazine Pages: 'A History of Conceptual Art'" (1985); Jeff Wall's essay "Dan Graham's Kammerspiel" (1985); Thomas Crow's Modern Art in the Common Culture (1996); David Campany's "Conceptual Art History or a Home for 'Homes for America'" (1999); and Benjamin Buchloh's "Moments of History in the Work of Dan Graham" (1978).
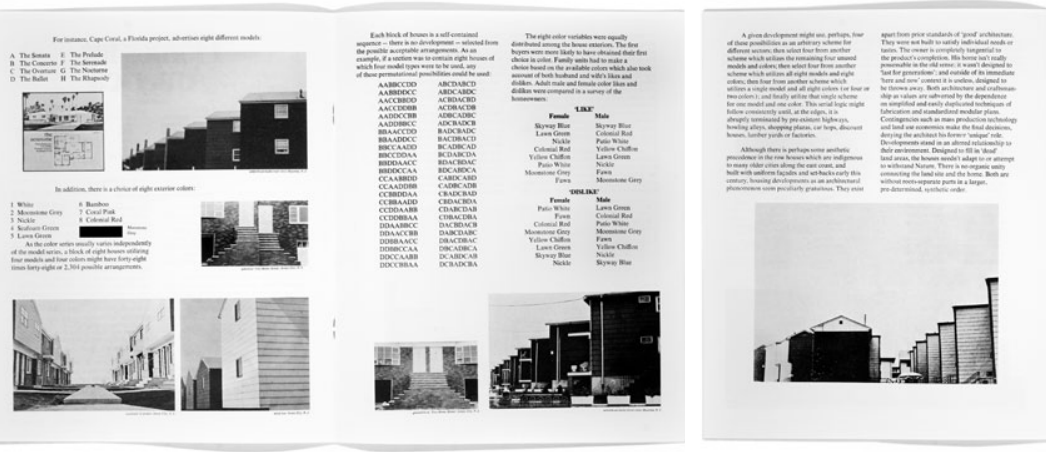

So despite the undisputed quality of the critical accounts of the piece-by Graham himself, but also by Jeff Wall, David Campany, Thomas Crow, Benjamin Buchloh, and others-the importance of actually seeing this progression proved to be key to my full understanding of the operation of this work. ${ }^{8}$ And, for me, this seeing could only be accomplished through a process of gathering and then comparing every different reproduction I came across (see Figure 8).

Indeed, when placed together, what these different reproductions demonstrate is a much clearer account of the precise evolution of "Homes for America:" from its initial conception as a set of photographic images; to the integration of these images and an associated text in a page-layout; to the insertion of this layout into the context of mainstream publishing (which introduced the first editorial alteration of the piece); and on to a series of further revised layouts, either though revisions to the paste-up by the artist himself, or through subsequently reformatted versions in further publications of the piece. And, importantly, what a clear understanding of this evolution demonstrates is how the work 
Figure 8

All courtesy the artist and Lisson Gallery.

(a) 1966 "Homes for America" began with Graham's Kodak Instamatic photographs of New Jersey suburban houses and diners, which he started in the early 1960s and, in 1966, projected as slides in the exhibition "Projected Art" at the Finch College Museum of Art in New York.

(b) 1966 However, in 1966, Graham also wrote and produced his pasted-up page layout for the piece as an illustrated magazine article, which included some of the original photographs alongside a written account of the particular style of the suburban tract housing in this suburb. He submitted this to Arts Magazine.

\section{(c) 1966-1967 Arts Magazine ran} the piece in the "Critique" section of their December 1966 - January 1967 issue, although they altered the page layout so that the article would run on from the previous article and into the next. The editor also dropped most of Graham's photographs and substituted instead a photograph by the established photographer Walker (c)

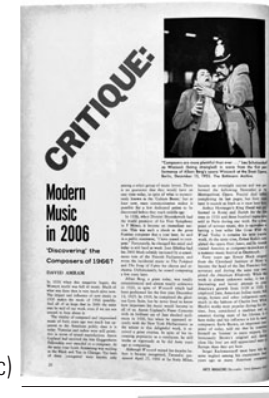

Evans whose images were popular in sociological journalism at that time.

(d) 1970 And then, in 1970, Graham produced another paste-up of "Homes for America", which, although re-presented as a double page spread, differs again in format from both his original paste-up and the Arts Magazine version and returns to the inclusion of Graham's original photographs. This version also often appears alongside critical accounts of "Homes for America" and, like the Arts Magazine version, is accepted and referred to as the work.

(e) $\mathbf{1 9 7 2}$ In 1972, a booklet was produced by Lisson Gallery in London (who represent Graham) and Koenig publishing - and here again a new layout for the piece was published, again returning to Graham's original photographs rather than the ones used by Arts Magazine.

(f) $\mathbf{1 9 7 5}$ And, in 1975, a booklet entitled For Publication, was produced by the Otis Art Institute in Los Angeles - with yet another published layout and set of images for the piece.

(f)
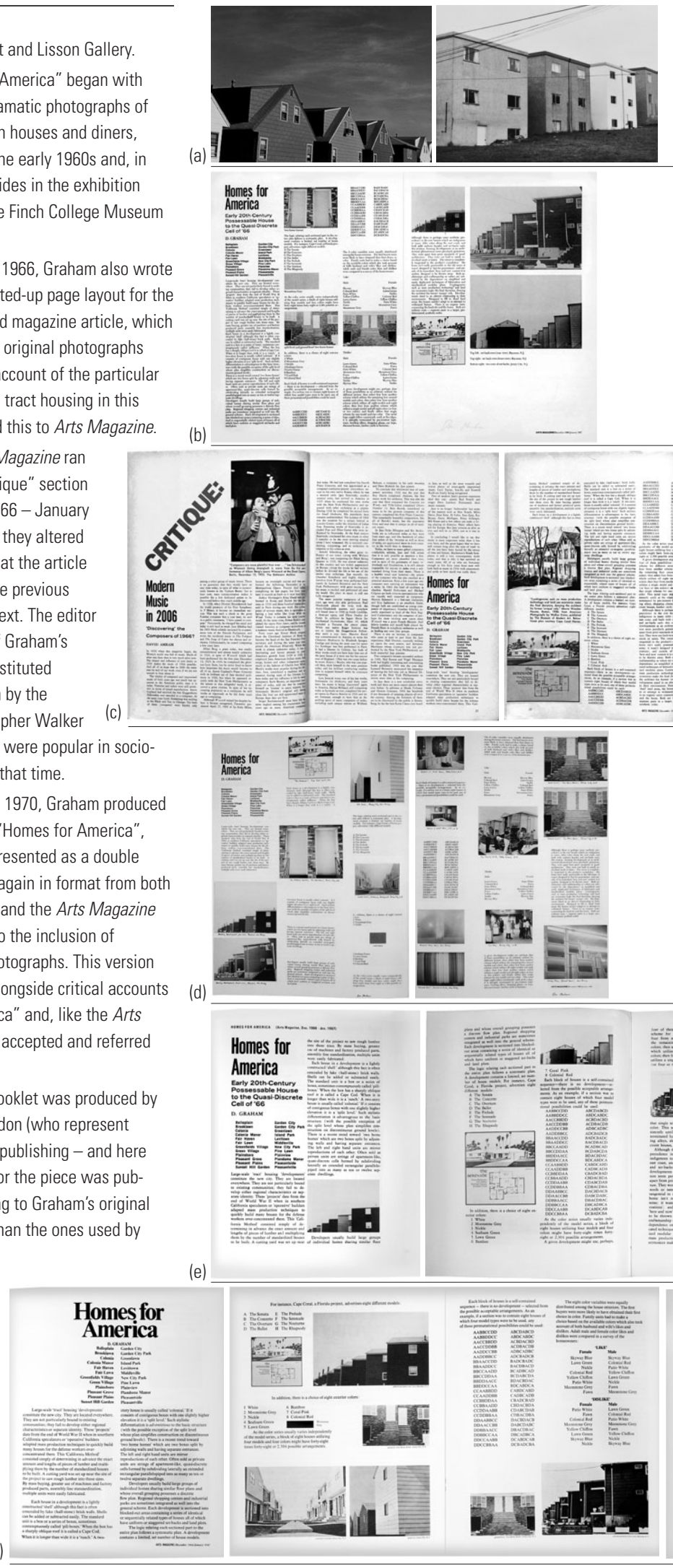

(d)
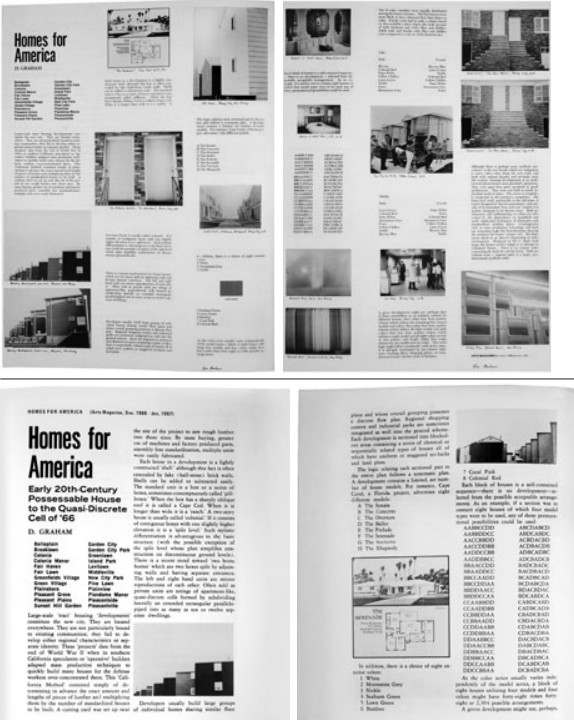

(e)

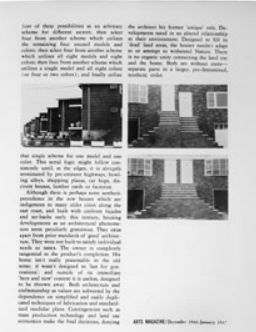


"Homes for America" can in fact be understood equally as any single one of these instances, or as all of them collectively as a number of constituent parts of an open-ended work.

\section{The Typographic Layout as Conceptual Artwork}

I have noted how accounts of "Homes or America" often refer to the ways in which the content and layout of the article's text and imagery connect back to the serial logic of Minimalist Art. These highlight Graham's focus on the pre-fabricated modular units of tract housing developments and his echoing of this arranged modularity through the typographic groupings and picture placements within the article (see Figure 4). In this sense, "Homes for America" can be considered alongside the text works of other artists like Carl Andre and Vito Acconci, who were engaged with similar interrogations of typographic layout during this period of the 1960s. In fact, in much the same vein, these artists applied classic Minimalist strategies, such as interruption, accumulation, fragmentation, and repetition to reduce and isolate texts into independent units.

The typographic arrangements of Andre demonstrate, for example, the potential for words to operate as a form of sculptural unit in the manner of the units (e.g., bricks, blocks, bales, and tiles) that he employed for his more conventional Minimalist sculptural works: ${ }^{9}$

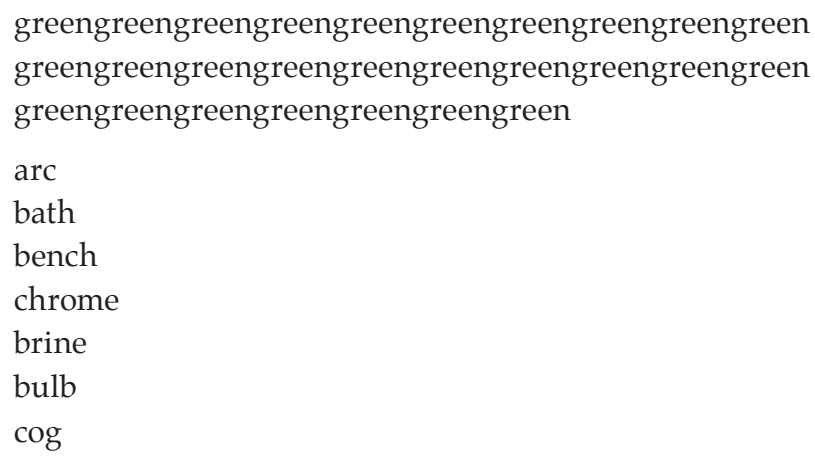

Indeed, for Andre, these arrangements of basic word-units act as an extension to his particular interrogation of the relationship between "the part (the 'cut')" and the overall sculptural unit. ${ }^{10}$

9 The first example here is an excerpt from Andre's poem "Green" (1960) and the second is an excerpt from Andre's poem "Essay on Photography for Hollis Frampton" (1963/4).

10 James Meyer, "Carl Andre: Writer" in Cuts: Texts 1959-2004, Carl Andre, ed. James Meyer (Massachusetts and London: The MIT Press, 2005), 12. Meyer also cites Craig Owens's discussion of this in his 1979 essay "Earthwords."

11 Carl Andre, transcribed interview from 1975, cited in Meyer, Cuts, 214
He acknowledged the link between his sculpture and these text works as follows:

My interest in elements or particles in sculpture is paralleled by my interest in words as particles of language... [I] write poetry in which the sentence is not the dominant form but the word is the dominant form. ${ }^{11}$

Robert Smithson describes this feature of Andre's text works in his 1968 article, "A Museum of Language in the Vicinity of Art," stating how "Each poem is a 'grave,' so to speak, for his metaphors. 

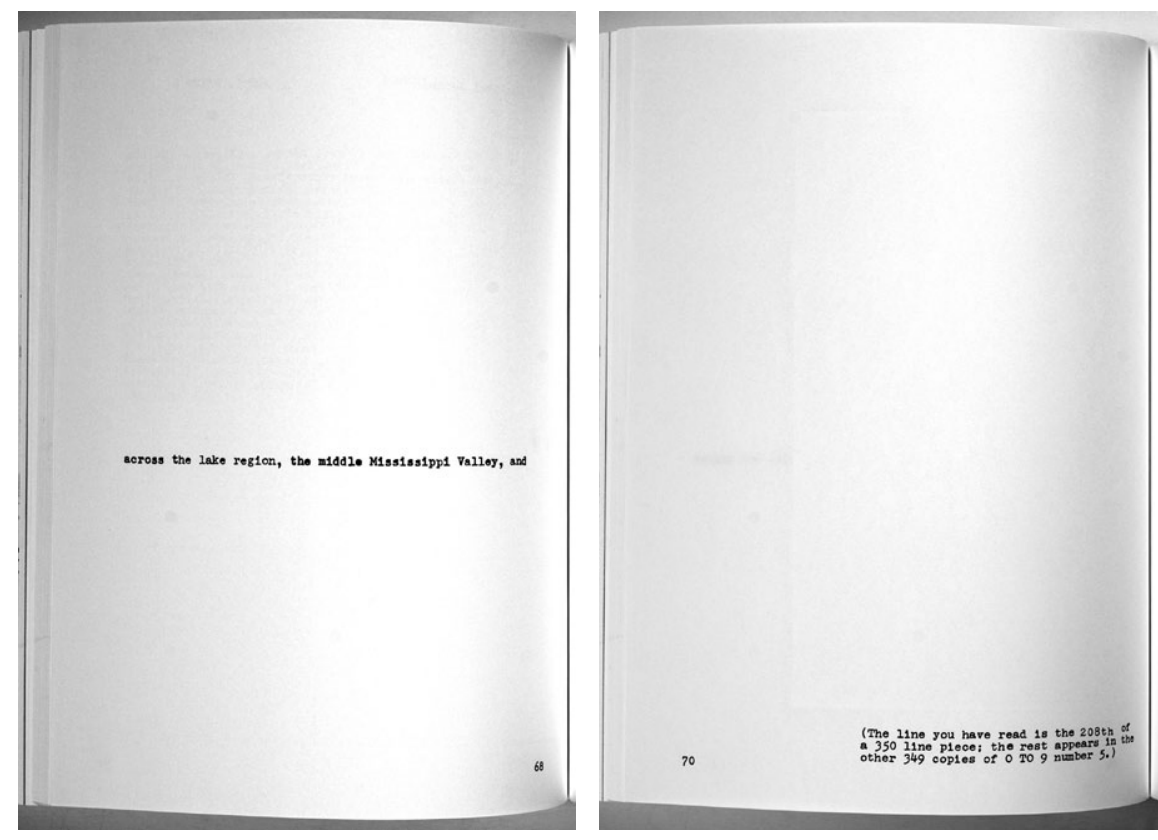

Figure 9

Vito Acconci, "Act 3, Scene 4", in 0 to 9, no. 5 (1969) (C) Vito Acconci; Courtesy the artist and Ugly Duckling Presse.

For this work, Acconci broke his text into 350 single lines, which are then separated across each of the 350 individual copies of this issue of the magazine. As a result, the work exists only as a fragment in each copy and, without looking at each, the reader/spectator can only imagine the whole piece.
12 Robert Smithson, "A Museum of Language in the Vicinity of Art," in Robert Smithson: The Collected Writings, ed., Jack Flam (Berkley: University of California Press, 1996 [1968]) 80, 84.

13 Ibid.

14 Many of which were published in the magazine 0 to 9, which Acconci produced with the poet Bernadette Meyer between 1967 and 1969. See Gwen Allen, Artists' Magazines: An Alternative Space for Art (Massachusetts and London: The MIT Press, 2011).
Semantics are driven out of his language in order to avoid meaning.... [H]is 'poems' and 'sculpture' have no mental or secondary qualities; they are to him solidly 'material."'12 However, in a further elaboration, Smithson articulates his own interest beyond what he calls "the physical properties of both language and material," and he states "they are both physical entities, but they have different properties, and within these properties you have these mental experiences, and it's not simply empirical facts." ${ }^{13}$

So, whereas Minimalist Art had by this time come to be seen as outdated and confined by its focus on the object, for Smithson, the important point about these text works was that, while initially focusing on the word as a material unit, they also demonstrated a shift into a more specifically language-centered interrogation. Thus, as constructions of text, they had the subsequent potential to expand away entirely from the confines of the object. In other words, although at first glance text-works like Andre's might appear to connect to concrete poetry (where text would be arranged semi-pictorially to evoke the poem's subject), what differentiates them is precisely the ways in which they echoed the shifting theoretical paradigms of visual art at that time by moving the object into a solely language-based context.

This shift is demonstrated well by the text-works of Acconci. ${ }^{14}$ Indeed, these specifically illustrate this evolution of the text from something material and static (which could still, to some extent, be passively looked at like an object) toward something much more shifting and dynamic, demanding a more conceptually orientated activity of reading from the spectator. As Acconci himself put it: 


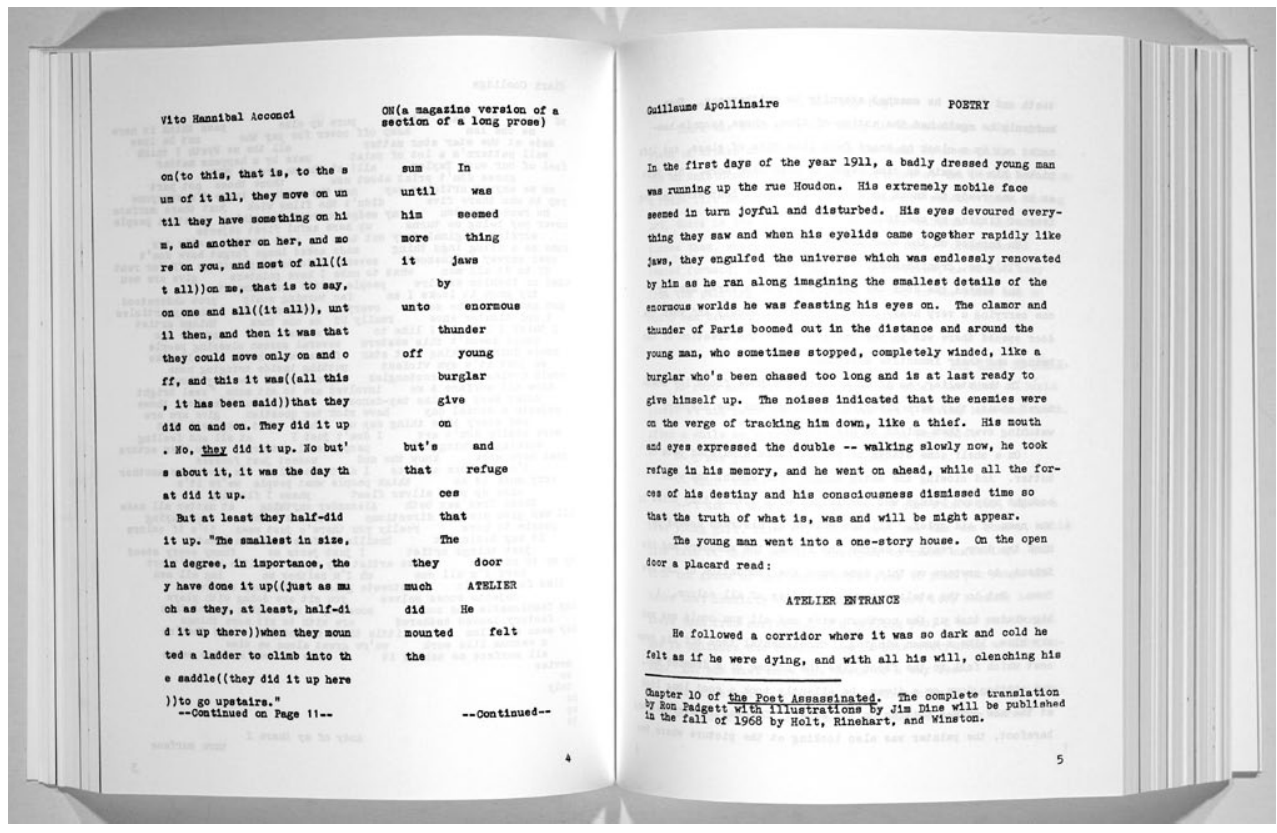

Figure 10

Vito Acconci, "ON", word cloning in 0 to 9, no.

3, (1968). (c) Vito Acconci; Courtesy the artist and Ugly Duckling Presse.

Acconci's texts in 0 to 9 are often non-linear in their arrangement on the page and intentionally disruptive to the linear reading of other surrounding texts: In this work, for example, his text appears across a number of pages, inserted between the texts of other contributors, and is created by cloning individual words from the pieces that immediately precede and follow it and arranging them in a scattered single-column. This establishes a relationship (or transaction) between the texts on either side which is described by Liz Kotz as a "word-transfer" or a "writing-throughproject" (2007) or by Acconci himself as a "transference installation" (1969).
A poem was already too much like a painting (most poems could be seen at a glance, on a single page). We wanted to move, from number to number, from word to word, from line to line, from page to page..$^{15}$

What Acconci's works particularly engaged with then was the interplay between reading and navigating around the self-enclosed pages of a document. As such, his text works were often situated across different copies or across several pages of the magazine (see Figures 9 and 10) and/or were dependent upon their relationship to the adjacent texts of other contributors (see Figure 10). Accounts of the operations of Acconci's text works, including his own 1972 essay "Early Work: Movement Over a Page," often therefore center around notions of temporality because of their disconnection from the perceived traditional or linear temporal mode and their move toward something more contingent and shifting.

And what these texts also introduced was a much more conceptually focused relationship between the work and the reader, which was increasingly achieved through a connection between the words on the page and the space in which the document was read. As Acconci himself described, he used the page as the beginning, or boundary, of an event that eventually left the page and occurred in some outside space. ${ }^{16}$

\section{Text as Readymade}

In many ways, the "Statement" texts of the artist, Lawrence Weiner (see Figure 11) establish a similar kind of conceptual text/reader relationship to the works by Acconci. Indeed, although Weiner,

16 Vito Acconci, "Early Work: Movement

Over a Page," in Avalanche, 6 (1972), 4-5. 
Figure 11

Lawrence Weiner, "Statements," as published in his book Statements (1968), front cover and inside page. Courtesy the artist, Lisson Gallery and Moved Pictures Archive NYC.
17 Osborne, Conceptual Art, 31.

18 Lawrence Weiner and Benjamin Buchloh in conversation, in Lawrence Weiner, ed., Alexander Alberro, Alice Zimmerman, Benjamin H. D. Buchloh and David Batchelor (London: Phaidon Press Ltd., 1998), 20.

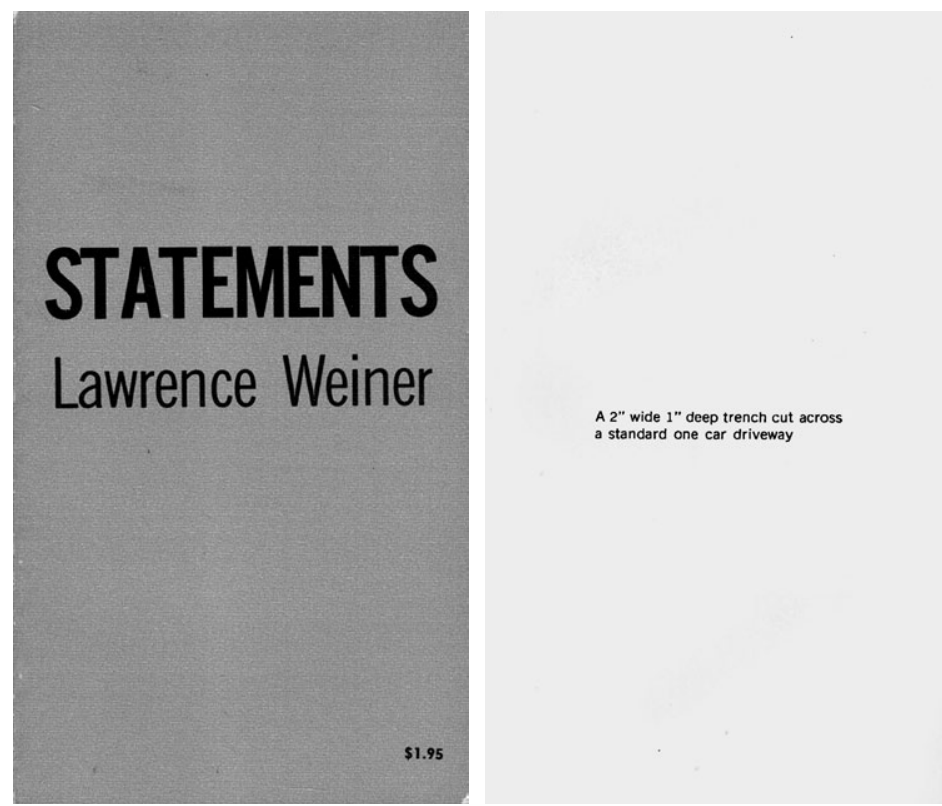

like Andre, was interested in the idea of language as a kind of sculptural material, his texts operate much more in the manner of Acconci's, gaining their sculptural qualities through the translation of material content into the mind of the "spectator" via the act of reading, rather than from looking at any particular form on a page. As Osborne puts it:

The "pieces" that Weiner states... are linguistically determinate. There is no question of their having existence as "idea" until they are formulated as statements; and no question of them being "pieces" until these formulations are actualized in some system of communication, in this case writing. ${ }^{17}$

In fact, although many of Weiner's Statements appear as handpainted or stenciled lettering on walls, when considering the operation of these works against the notion of texts to be read rather than looked at, one should primarily consider the examples he positioned as typeset texts in published documents and, in particular, examples that were presented in a purposefully utilitarian style:

Take [the book] STATEMENTS: There is a design factor to make it look like a $\$ 1.95$ book that you would buy. The type-face and the decision to use a typewriter and everything else was a design choice..$^{18}$

Thus, as with Graham's "Homes for America," it is the specifically neutral appearance of these published Statements that helps these examples to shift away from notions of authorship and objecthood. And their particularly utilitarian typographic style also serves to connect them back to earlier examples of typewritten text works, 
Figure 12

Joseph Kosuth, "Proto-Investigation: 'One and Three Saws'" (1965) (C) Joseph Kosuth/ ARS, NY and DACS, London, 2012. Courtesy Sprüth Magers Berlin London.
19 Liz Kotz, Words to be Looked At: Language in 1960s Art (Massachusetts and London: The MIT Press, 2007), 51.

20 As articulated for example, in Joseph Kosuth's essay "Art after Philosophy" (1969) where he depicts Duchamp's work as key to a revision of art history whereby the Readymade, rather than the evolution to and beyond formalist abstract painting, is posited as central to the critical collapse of medium-specific modernism.

21 Anne Rorimer, "Siting the Page: Exhibiting Works in Publications: Some Examples of Conceptual Art in the USA," in Rewriting Conceptual Art, eds., John Bird and Michael Newman (Reaktion Books Ltd., London, 1999), 17.

22 Here, for example, Kosuth published thesaurus texts directly into the advertisement sections of newspapers or onto billboard-sized street advertisements.
Due to copyright restrictions this image can only be reproduced in the print version of Design Issues 29, no. 2.

such as John Cage's score for the work "4'33"," which as Liz Kotz discusses, had similarly rejected the fetishization of the handdrawn mark and moved toward "vernacular signs so repeatable and translatable that no original appears to exist."19

These examples by Weiner become useful then, alongside those of Graham, in demonstrating the retrospective art historical connection that has been drawn between text-based Conceptual Art and Duchamp's concept of the Readymade, which in 1913 had already used language to propose a shift in the assignment of meaning from non-art to art. ${ }^{20}$

Moreover, what works like these serve to illustrate is Graham's proposed extension to the Readymade idea, as articulated in his 1985 essay, "My Works for Magazine Pages: 'A History of Conceptual Art.'" Here, he claims that, through its particularly neutral appearance and ubiquitous nature, the published text work has the potential to possess a dual (or oscillating) status as both non-art and art, existing simultaneously both within and outside the Institution. In fact, Anne Rorimer makes this same point in her discussion of the artist Joseph Kosuth's investigations of "art as an analytical proposition," describing, for instance, the way in which his appropriated dictionary definitions (see Figure 12) operate "by virtue of the capacity of [typographic] language to be what it is and what it is about simultaneously." ${ }^{21}$

\section{The Undifferentiated Continuous Text as Conceptual Artwork}

The further interesting shift in Kosuth's use of text came, however, when his investigations dispensed with photocopied dictionary definitions, and moved instead toward the publishing of definitions of possible art information directly into non-art channels of communication. ${ }^{22}$ Indeed, for Kosuth, this not only got around the potential for the works to fall into any kind of pictorial illusionism, but more importantly, it also allowed him to shift his focus entirely 


\section{Figure 13}

Joseph Kosuth, “The Tenth Investigation

(Art as Idea as Idea): 'The Information Room'"

(1970). Installation realised in various

locations, including galleries and libraries:

Installed here at Sprüth Magers Munich

in 2005. (c) Joseph Kosuth/ ARS, NY and

DACS, London, 2012. Courtesy Sprüth

Magers Berlin London.
23 Anne Rorimer, New Art in the 60s and 70s: Redefining Reality (London: Thames \& Hudson Ltd., 2001), 100.

24 Which included Kosuth for a time amongst its shifting membership.

25 Terry Atkinson, et al., introduction to Art-Language: The Journal of Conceptual Art, (Coventry: Art \& Language Press, 1969), 10.

26 These "overlapping contexts" included conversations within the group and active involvements within art education.
Due to copyright restrictions this image can only be reproduced in the print version of Design Issues 29, no. 2 .

toward the staging of art as pure information. His final investigations therefore moved toward the idea of art existing more as a kind of dynamic theoretical and critical commentary that might involve the navigation through (or the origination of) a series of extended and typographically undifferentiated continuous texts.

In "The Information Room," for example, various forms of printed continuous text were exhibited on reading tables in an exhibition space that was described as "a venue for knowledge rather than... a container for objects." Here the work, although "physically contained" in the room, was-through its very textual form-able to take the reader conceptually beyond the physical confines of the space (see Figure 13). ${ }^{23}$

This use of text to position art within the intellectual space of theoretical and critical commentary was most fully elaborated, however, by the group, Art \& Language. ${ }^{24}$ This group used its practice in the late 1960s and early 1970s to consider whether theoretical analysis itself could constitute a "method for... making art." ${ }^{25}$ And, although they used a number of overlapping contexts for their inquiry, their use of typographic language was a key aspect of this process. ${ }^{26}$

Of particular importance was the group's exploration of the editoriallessay as artwork, which they undertook through their production of typeset continuous texts, situated within the bound format of a published journal (see Figures 14 and 15). Here, the neutral typographic design of the journal with its white cover and pages of un-illustrated text, echoes again the attempts by others to divest their works of any authorial/artistic voice, so that the reader engages with these texts through a process of reading, without any question that they should perhaps be looking at the journal as a visual object. However, in the introduction to the first issue, the group advanced a new hypothesis that elaborated more 
Figure 14

Art \& Language, Art-Language journal (1969-

85). Selection of front covers from vols 1 and 2

(1969-72). (C) Art \& Language; Courtesy the artists and Lisson Gallery.

\section{Figure 15}

Typical page spread from the Art-Language journal (1969-85). (C) Art \& Language; Courtesy the artists and Lisson Gallery.
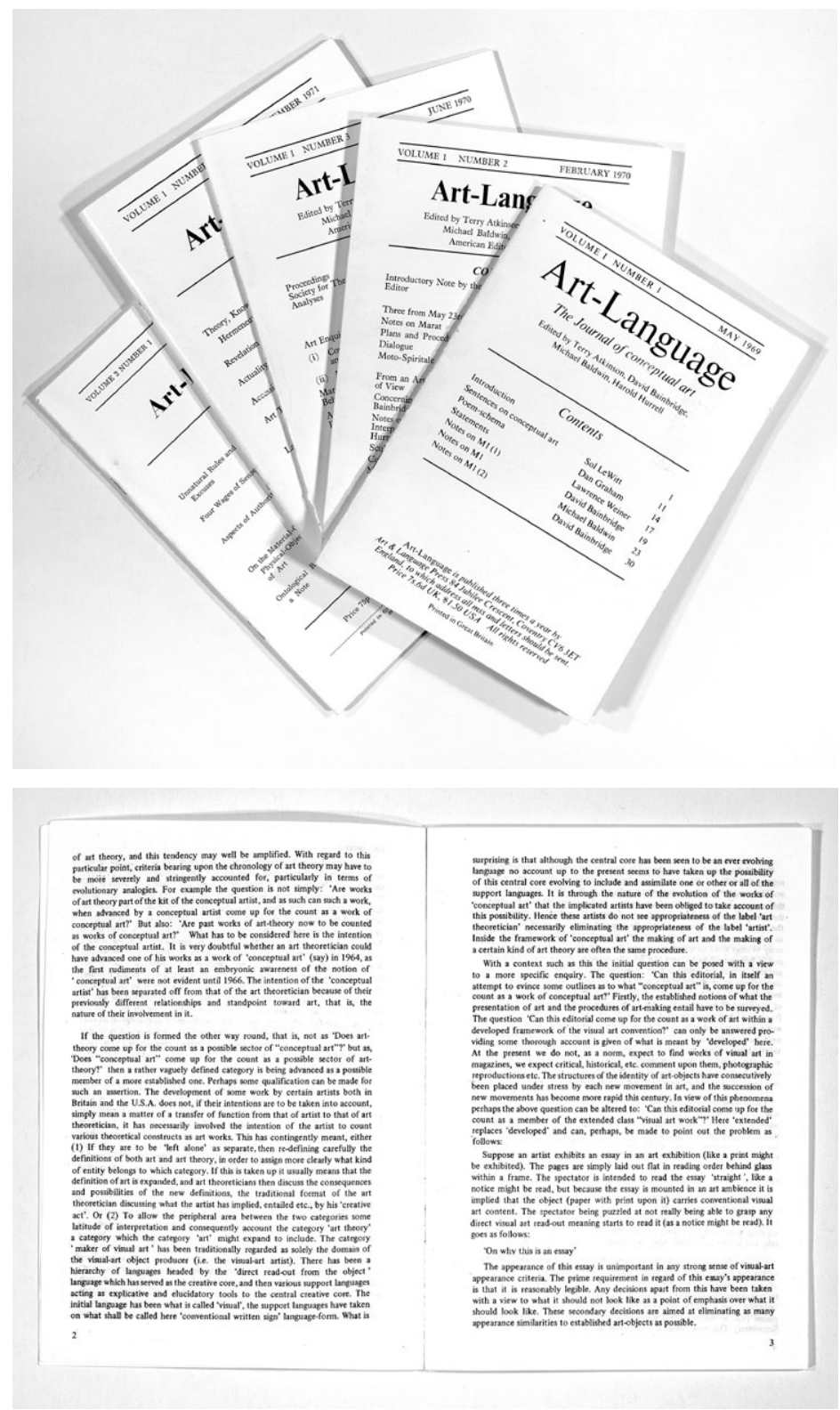

specifically on the particular need for this completely neutral textual appearance: That the content of the editorial "is [itself] held out as a 'conceptual art' work" through its critical or theoretical content alone. An excerpt from the introduction thus reads as follows (see Figure 16):

Suppose an artist exhibits an essay in an art exhibition (like a print might be exhibited). The pages are simply laid out flat in reading order behind glass within a frame. The spectator is intended to read the essay "straight," like a notice might be read, but because the essay is mounted in an art ambience it is implied that the object (paper with print upon it) carries conventional visual art content. The 
Figure 16

Art \& Language, excerpt from the introduction to the first issue of the Art-Language journal (1969). (c) Art \& Language; Courtesy the artists and Lisson Gallery.
27 Atkinson, et al., introduction to Art-Language, 3.

28 Ibid., 6-7.

29 Charles Harrison and Paul Wood, "Modernity and Modernism Reconsidered" in Modernism in Dispute: Art Since the Forties, eds., Paul Wood, Francis Frascina, Jonathan Harris and Charles Harrison (New Haven and London: Yale University Press, 1993), 208
Suppose an artist exhibits an essay in an art exhibition (like a print might be exhibited). The pages are simply laid out flat in reading order behind glass within a frame. The spectator is intended to read the essay 'straight ', like a notice might be read, but because the essay is mounted in an art ambience it is implied that the object (paper with print upon it) carries conventional visual art content. The spectator being puzzled at not really being able to grasp any direct visual art read-out meaning starts to read it (as a notice might be read). It goes as follows:

'On why this is an essay'

The appearance of this essay is unimportant in any strong sense of visual-art appearance criteria. The prime requirement in regard of this essay's appearance is that it is reasonably legible. Any decisions apart from this have been taken with a view to what it should not look like as a point of emphasis over what it should look like. These secondary decisions are aimed at eliminating as many appearance similarities to established art-objects as possible.

spectator, being puzzled at not really being able to grasp any direct visual-art-read-out-meaning, starts to read it (as a notice might be read). It goes as follows:

"On why this is an essay"

The appearance of this essay is unimportant in any strong sense of visual-art appearance criteria. The prime require ment in regard of this essay's appearance is that it is reasonably legible. Any decisions apart from this have been taken with a view to what it should not look like as a point of emphasis over what it should look like. These secondary decisions are aimed at eliminating as many appearance similarities to established art-objects as possible. ${ }^{27}$

Art \& Language used their introduction to further describe the absence of any defined exhibition instruction and to articulate how "the art-gallery component had to be specified... [by the editorial] as a theoretical rather than a concrete component." ${ }^{28}$ However, what is interesting here is how the group subsequently moved on from this idea by repositioning the printed pages of the journal back into a more conventional exhibition environment as part of their work "Index 01" (see Figure 17), a process through which they were able to undertake further more controlled interrogations of the reading of these texts.

Indeed, by using this context to force a particular kind of cross-referencing reading strategy, what this exhibit conveyed was how the content of the individual journal texts could be extended in any number of ways through their endless potential for reference to other similar texts. This cross-referencing was used to demonstrate how "the kinds of decisions we make about the relations between one text and another can have implications for our picture of [how one might conceive of] an entire conversational, or ideological world."29 


\section{Figure 17}

Art \& Language "Index 01" (1972). Eight file cabinets, texts and photostats. (c) Art \& Language; Courtesy the artists and Lisson Gallery

In "Index 01", the unbound printed journal pages from Art-Language and other texts by the group were contained within the drawers of eight metal filing cabinets, and a cross-referencing reading strategy was then suggested by assigning each text an index number and displaying a proposed "system of connections" (along with its results) in the form of printed index lists on the walls of the exhibition space.

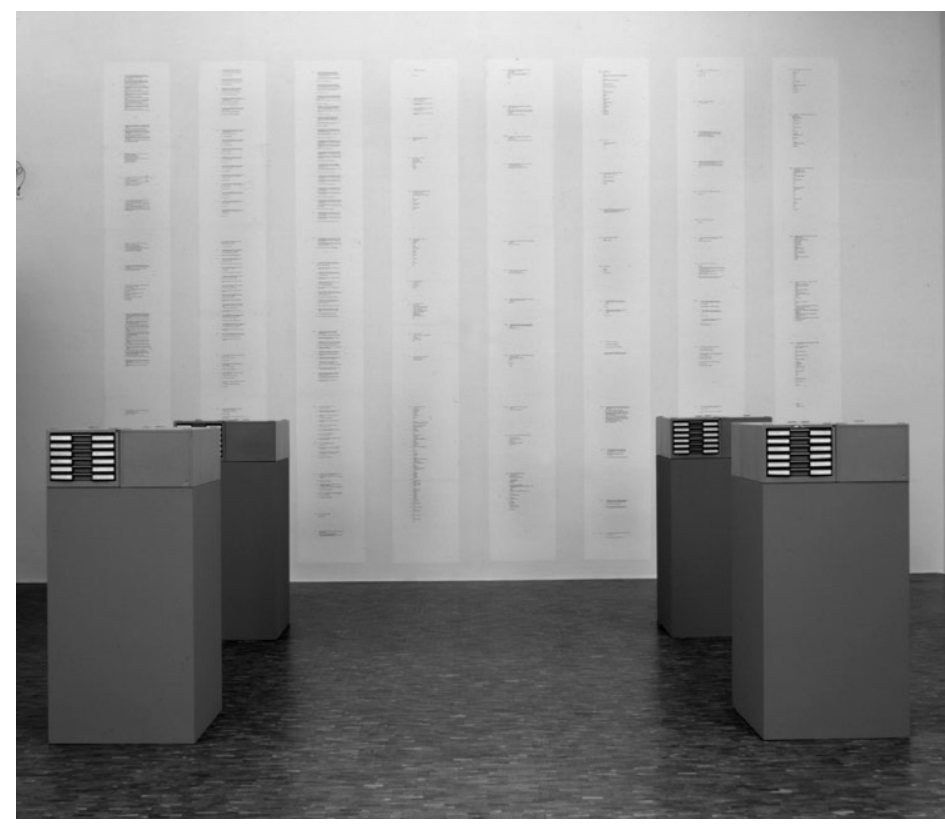

The Integrated Text as Conceptual Artwork

I turn now to the layout of a published article by Robert Smithson, which not only seems to fit in here, around the point I have reached with the journal pages of Art-Language, but also-because of its existence as a magazine article, and the year in which it was published-connects back to my earlier consideration of Graham's "Homes for America."

Smithson's article, "Quasi-Infinities and the Waning of Space," was published in the November 1966 issue of Arts Magazine just prior to the magazine's publication of Graham's "Homes for America" (see Figure 18). And since Smithson, unlike Graham, had clearly had the opportunity to specify his own page layout, he used this as a key component of the work. His method was thus to break the text into separate blocks so that the main commentary could be surrounded by textual and visual marginalia, which would integrate with the main body of the document to facilitate a cross-referencing style of reading.

In her book Chronophobia, Pamela Lee describes this use of page layout in relation to Smithson's interest in a constellation of meaning. ${ }^{30}$ She points to the inclusion, in Smithson's marginalia, of references to the writings of the anthropologist and architectural historian George Kubler and the cyberneticist Norbert Weiner, whose preoccupations included non-linear and metaphorical representations of past historical time and future communication systems. ${ }^{31}$

So, despite there being no obvious connection between the integrated arrangement of Smithson's article and the singlecolumn, un-illustrated, essay-like texts of the Art-Language journal 


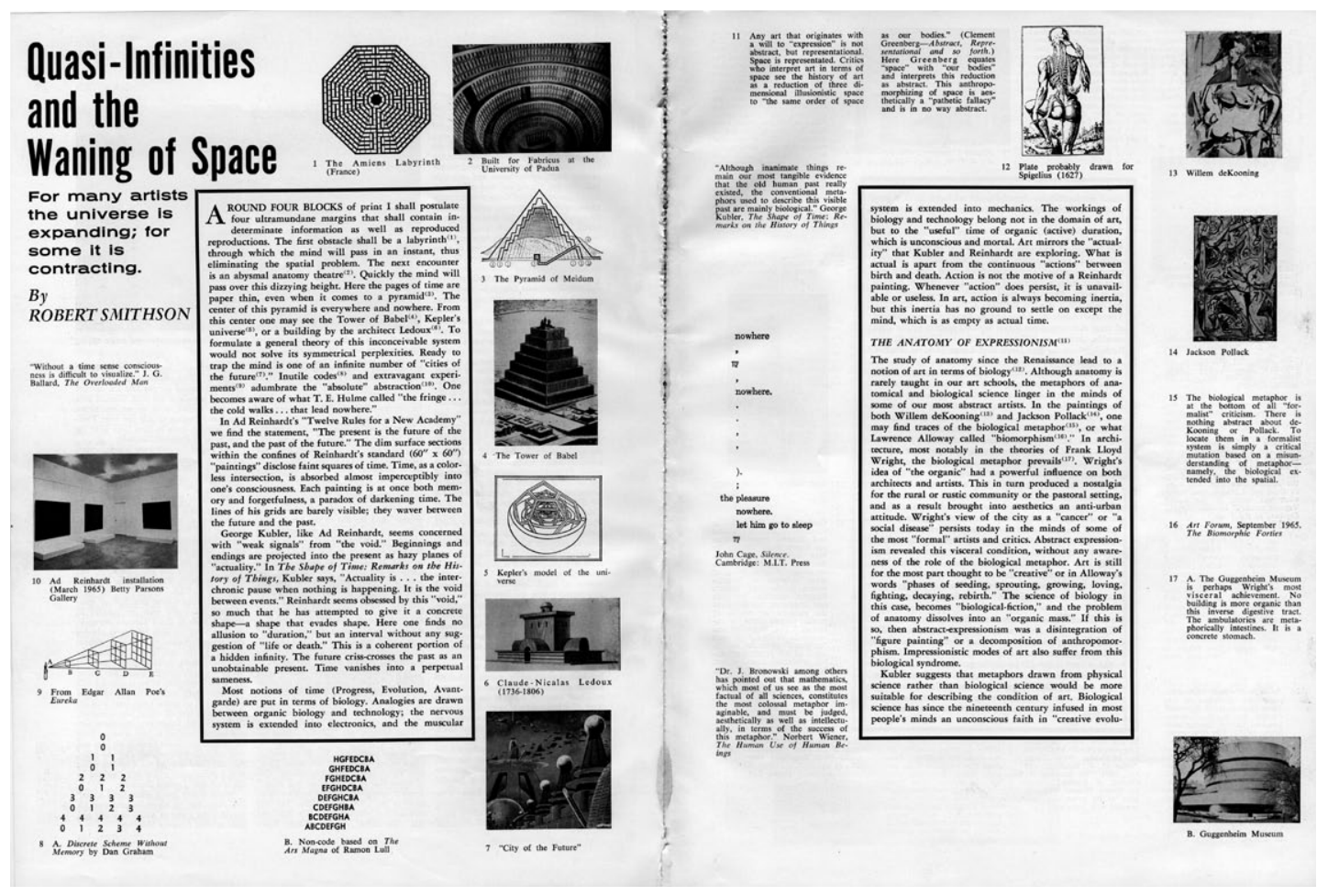

Figure 18

Robert Smithson, "Quasi-Infinites and the Waning of Space," published in Arts Magazine, vol. 41, no.1, (November 1966). Image courtesy James Cohan Gallery, New York/Shanghai. (C) Estate of Robert Smithson/ Licensed by VAGA, New York, NY.
32 The artist Seth Price explores this shift in his essay "Dispersion," free pdf download at www.distributedhistory.com (2002-ongoing).

33 lan Burn and Mel Ramsden, Notes on Analysis, excerpt reproduced in Six Years: The Dematerialization of the Art Object from 1966 to 1972, ed., Lucy Lippard (Berkley: University of California Press, Ltd., 1973 [1970]), 137.

34 Osborne, Conceptual Art, (2002). (see Figure 15), Smithson's use of both subject matter and layout seems rooted in a similar territory to that of the infinite possibilities for cross referencing content, as presented by Art \& Language in their later work "Index 01" (see Figure 17).

And it seems apt then to refer to a 1970 text by Art \& Language's Ian Burn and Mel Ramsden. This text seems to present not only an end point for this discussion but also perhaps a starting point for thinking about subsequent post-Conceptual engagements, which have seen a shift from the distribution of text-based artworks through print toward practices that are situated entirely within the interactive and networked channels of digital publishing: ${ }^{32}$

Since an art object by now "might conceivably be anything on the face of this planet," then "it would be dumb to insist on nominating an analytic art construct (i.e., this paper) as an 'artwork.'"'33

Indeed, as Osborne observes with reference to this text:

Conceptual artists [had] turned their concern not to "the proliferation of designated signifieds" but to the "semiotic mosaic" from which meaning was derived... [This was the new question:] How was the "continuum," the system, the structure-as-a-whole itself to be made the content of the work? ${ }^{34}$ 
Figure 19

Page layouts by Katherine McCoy and a team of Cranbrook students for Visible Language. Special issue French Currents of the Letter, vol. 12, no. 3, (Summer 1979). Courtesy the Department of Typography \& Graphic Communication, the University of Reading UK.

These pages (308-9 and 372-3) show progressive interruptions to the text setting, which were applied throughout this issue of the journal to disrupt any standard linear reading of the text.
35 Richard Hollis, Graphic Design: A Concise History (London: Thames and Hudson, 2001), 214

36 J. Abbott Miller and Ellen Lupton, Design Writing Research: Writing on Graphic Design (New York: Kiosk, 1996), vi; and referred to within Figure 20, Katherine McCoy with David Frej, “Typography as Discourse," in ID magazine (New York: March/April, 1988), 34-37.

37 Steve Baker, "A Poetics of Graphic Design," in Visible Language, special issue New Perspectives: Critical Histories of Graphic Design, Part 1, vol. 28, no. 3 (1994).

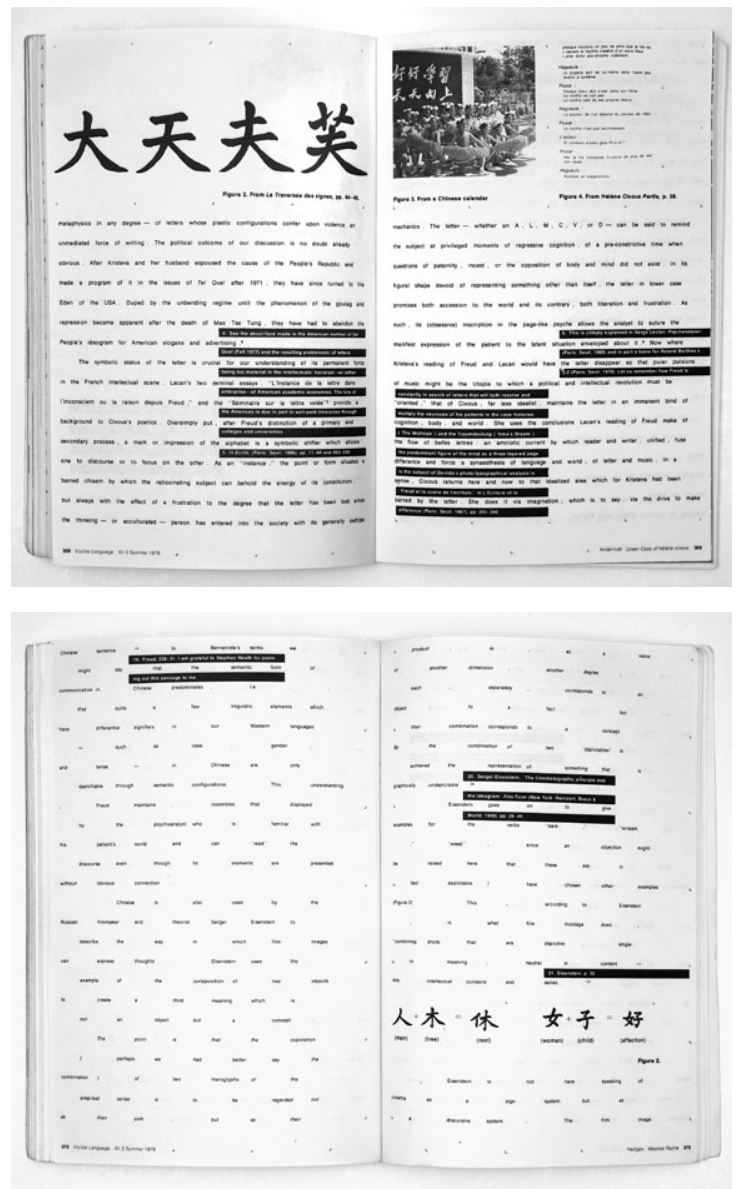

What Relevance to Typographic Discourse?

One can look in a number of directions to see connections between these examples of text-based Conceptual Art and the more general discourse of typographic design: These art engagements of the 1960s and 1970s can, for example, be considered against experimental typographic practices, which emerged in the United States between the 1970s and the 1990s where, as Richard Hollis notes, designers were becoming "more aware of the need for theory and history to back up their own practice." If one looks, for instance, at the design journal, Visible Language, and its development of what Hollis calls a "critical [rather than purely technical and historical] view of graphic design" (see Figure 19); ${ }^{35}$ or at the related practices and discourses at Cooper Union and Cranbrook Academy, where students were encouraged to "think about art and design in terms of culture and language" (see Figure 20); ${ }^{36}$ or at the new layout and content relationships explored by a magazine like Émigré (see Figure 21), ${ }^{37}$ one can see how these works demonstrated a similar desire to move beyond the critical framework of modernist formalism, toward more active engagements with the reader. Indeed, the 
Figure 20

Katherine McCoy's poster design “Cranbrook Graduate Design" (1989) from Cranbrook Academy of Art. Courtesy Katherine McCoy.

As McCoy put it in her 1988 essay

"Typography as Discourse": "No longer are there one-way statements from designer .. both the texts and the images are to be read in detail, their meanings decoded. Clearly this intellectualized communication asks a lot of its audience; this is harder work that the formal pleasures of New Wave." (see note 36)

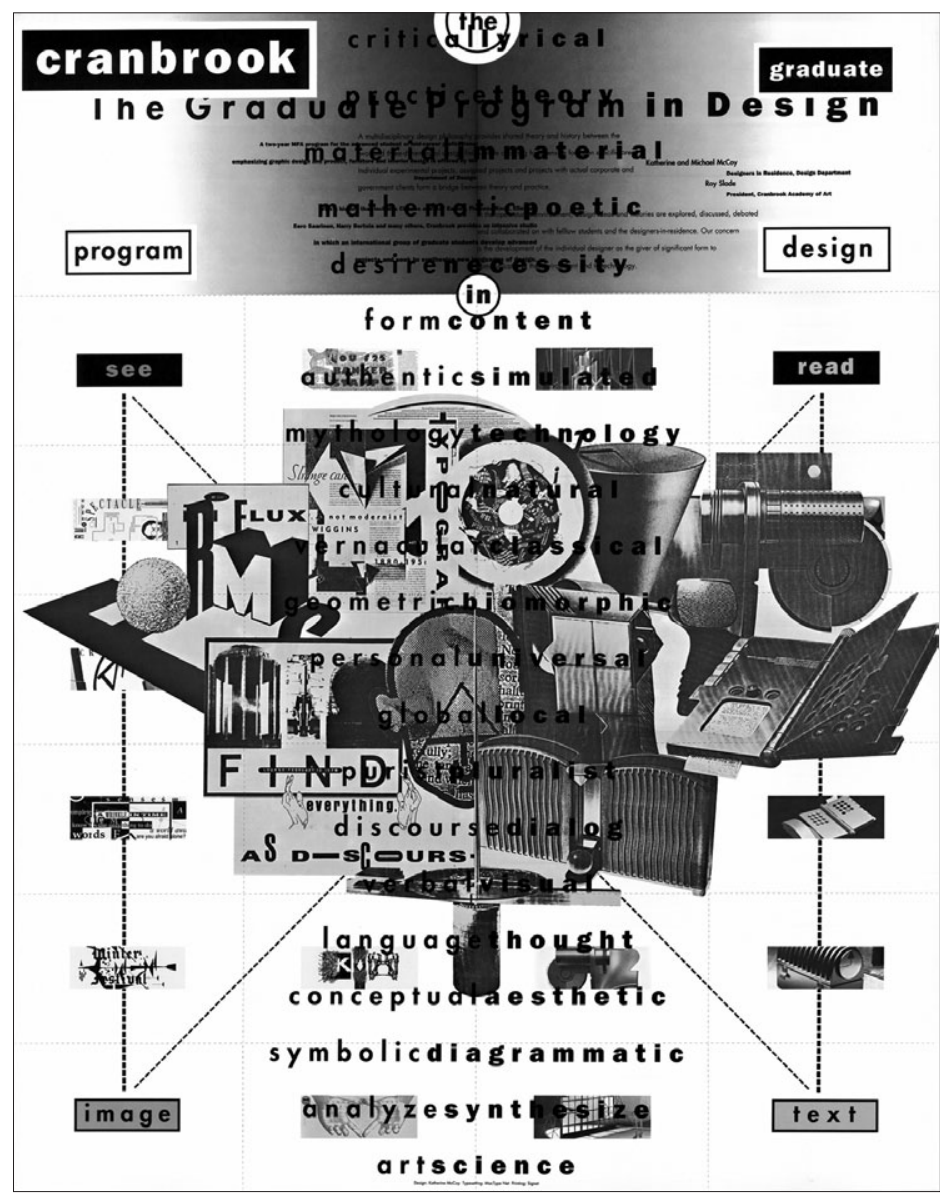

discourse surrounding these examples locates itself equally against the evolution of structuralism into post-structuralism and references the same theoretical ideas and precedents in literature and poetry as cited in accounts of text-based Conceptual Art.

As such, whereas these experimental typographic practices were attacked in the 1990s by critics like Robin Kinross for being poor interpretations of a set of rarefied theoretical ideas, which led to counter accusations of a kind of "zombie modernism" in typographic discourse, what these connections demonstrate is how the example of text-based Conceptual Art could contribute a much more stringent point of reference to such critical debate. ${ }^{38}$ Indeed, if one considers how, despite these cross-disciplinary references to a shared historical and theoretical lineage, the critical collapse of modernism in art had not been to the same degree replicated in the field of typographic design, it seems obvious to propose that one has to look at such examples of 1960s art to gain an understanding of the full significance, both historically and theoretically, of this shift towards active typographic engagement. 

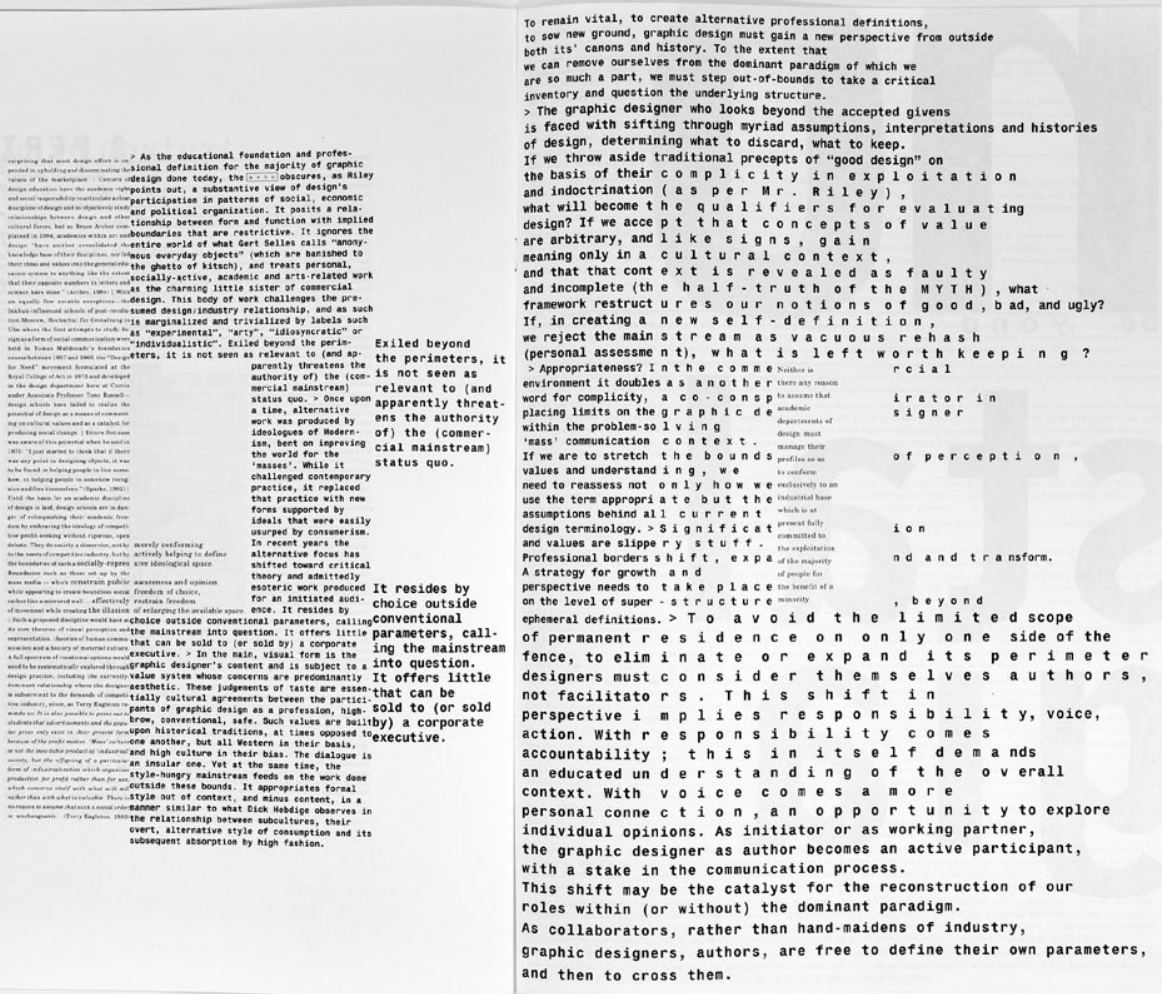

Figure 21

Anne Burdick's page layouts for Émigré 21

(1992). Courtesy Anne Burdick.

As Steve Baker observes, this approach to layout "heralded the use of graphic 'interpretation' to deflect and enrich the trajectory of the critical text." (see note 37)

39 The work of Dexter Sinister began, for example, through the publication of a graphic design journal (Dot Dot Dot) and has evolved into a series of extended engagements with the activity of publishing, staged increasingly within art contexts such as the Whitney Biennial (New York, 2008) and the Museum of Modern Art's exhibition "Ecstatic Alphabets/Heaps of Language" (New York, 2012). However since their practice remains very much focused on typographic processes and acts of publishing, the work of Dexter Sinister (Bailey and Reinfurt) and The Serving Library (Bailey, Reinfurt and Keefer) remains popular with graphic design students and practitioners and they are often invited to participate in schools and events more conventionally associated with design than art.
What then seems also relevant is that examples of 1970s1990s experimental typography are in fact similar in their scope to the kinds of interrogation undertaken by an artist like Vito Acconci. As such, it can be further proposed that the progression of textbased Conceptual Art into more extensive interrogations of the active contexts of publishing (as with the practices of those like Graham, Art \& Language, and Smithson) provides a more expansive set of engagements that are useful as a point of reference for contemporary publishing practices like those of Dexter Sinister and The Serving Library or the artist Seth Price, which have even more overtly straddled the disciplines of art and typographic design (see Figure 22). Indeed, the desire to engage with such contemporary practices in both art and design contexts seems to point again to the need for this lineage to be understood and incorporated more rigorously within mainstream typographic discourse. ${ }^{39}$

In short, rather than focusing on "for" or "against" arguments in response to self-initiated typographic practices where designers might be seen equally as artists, or sidelining these trajectories as "experimental," typographic discourse should perhaps be willing to understand the role of this art lineage in defining a 
Figure 22

Stuart Bailey, Angie Keefer and David Reinfurt (eds). Text excerpt from "Article of Incorporation" (2012), reproduced at the back of each issue of Bulletins of The Serving Library. Courtesy The Serving Library.

\section{The Serving Library: ARTICLE OF INCORPORATION}

The Serving Library is o cooperatively-built archive that assembles itself by publishing. It will consist of 1 . on anbitious public wobshe, 2. o small physical hibrory spoce, J a publishing IN OTHER WORDS Here is a thought-experiment. Imagine yourself in a virtual
spoce surnounded by icons: a claustrophobic negotive photo (ape book in a heraldic shield, underscored by the phrase "Lux et Veritas" - Light and Truth; a mon blowing whot oppears to be a handful of feathers but turns out to be a disintegrating book; o curious-looking alien glyph; o fomiliar aptical illusion that looks like onother open book projecting first out then in then out ogain; and an odometer on the brink of changing from 9999999 bock to zero.

These are the front poges of a number of Portable Document Formats, and this is www. servinglibrary. org. engine room of The Serving Library. Eoch PDF is a "Bulletin" contoining an article or essay that constitutes part of some overarching theme or hemes in his cose, from specinc to gener Labro large asterisk, for example, con temploce the possibilies for attributes of the Octopus Vulgaris. As it tums out, that

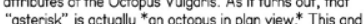
"asterisk" is actually "on octopus in plan view* This ond the Contributions to the latest theme ore odded from fime to tim over a six month period, and at the end of the season they are collected together into a single document, printed and published in both Europe and the USA, each in an ecition of 1,500, os Bulletins of The Serving Library. The PDFs remain available on the website, while a new theme is developed over the nex half year

One copy of Bulletins of The Serving Librory is bound in hardback leatherette, cotologued, and ploced on a shelf in the physical home of The Serving Library. Here it joins past issues, along with twenty issues of its predecessor, the leftfield arts journal Dot Dot Dot. A neighboring shelf carries a larger collection of older, most frequenty referenced book Bullins cort, Bullefins - on ant, litroture, philosophy, and so on - thot interests. And on onother shelf, is a further assortment of relatively recent titles covering a wide gamut of contempora publishing that had been sold from - cnd of en published publishing that had been sold from - ond offen published by - Dexter Sinister, o design workshop and bookstore on
Monhattan's Lower Eost Side that wos run as a primitive form of The Serving Library by two of its founders from 2006-2011

The wolls that surround these shelves are hung with seventy or so fromed ortifocts. These are wildly diverse in

size and medium, from a huge red wax crayon rubbing of a "Monument to Cooperation" (the original of which is located outside o housing estate, around the corner from Dexter Sinister) to a double portrait of Benjamin Fronklin (the clossi etching of o smug Postmoster General next to o photo taken of four people checking for evidence of forgery in a giant blow-up of the same portrait on a fake US\$100 bill, otherw knoun as a North Koreon "Superdolla" "O Other objects include paintings, ithogrophs, record covers, faxes, acid blotter appeoned, sconned or photographed, os an illstration in issue of Dot Dot Dot or the Bulletins tupiolly accompanying or triggering a piece of writing. As such, each one has an or triggering a piece of writing. As such, eoch one has an
eloborcte bockstory. The ouijo board, for example, was made

BoTSL+3 2012 APR 152.56 PM

\section{9}

particular type of post-Conceptual inter-disciplinary engagement that continues to interrogate how an active engagement with structure can indeed become the content of the work. by British polymath Poul Elliman while a professor in design of Yole University in the early 2000s. It utilizes a version of the $0-9$, a "yes" and o "no," loser-cut from a squore of the same $0-9$, a "yes" and a "no,"loser-cut from a square of the Bulletins published from The Serving anecdotally-loaded objects to be sought, ocquined, framed, and added to the woll

A resident coretoker presides over these two collections of publications and artifocts. This is a rotating position which turns combine those of a regular librarian - cataloging, maintaining. and updating the collections - with those of an events organizer and editor. The caretcker is a constant presence of The Serving Library, avalicble to open its doors to groups or individuals by appointment, then to supervise and direct their the collections, drowing out certain bocks for display - perhops highlighting an esscy in an early Dot Dot Dot that explicates one of the artifacts, or juxtaposing some of the older, classic
books in order to troce o history of, soy. Progmatic philosophy. books in order to trace a history of, scy, Progmatic philosophy Or, equally, reassembling the artifacts - chronologically. involved, to a greater or lesser degree, in the production of the Bulletins published during his or her tenure, Ideally ossuming the necessary skills, experience ond insight, he or she will guest-edit the seoson's moterial, proposing, coercing, and working on contributions.

The caretaker olso oftends - and attends to - a modest pedogogical program, which tokes place in the Library environment during an allotted period every year. It is based on a reconsideration of the troditional Bauhous Foundation to specific cultural conditions almost a hundred years ogo, why does it remain the stondard today? Through the Library course, this question is considered in relation to the Photoshop toolbox icon - odopted essentially as a surrogate for any contemporary arts soffware. Working backwards from the fact that such digital "creative suites" constitute the consensus of commerciol demand, various guests from different fields will then discussing its cnologue past, virtud, magesent, and potentio future. These investigations are conducted through seminers and workshops, which draw frequently on the Librory's This reconsideration proposes - initiolly for the sake of
Taright. argument - that color wheels, circles, triangles and squares and other principles of cross-disciplinary "basic design" are less relevant today than a communal effort to observe and relate contemporary conditions, by practicing the forms of reading, writing, and speaking that facilitale their articulation to comprehend the culture in which art and design operote in advance of (or porallel to) operating in it.

As new component classes are clipped onto the bosic "hande over time, a new mefophorical foalbox is assembled by the Library, which reploces the old foundation with something more flud, pertinent and retexive. And this customized,

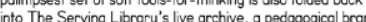
of serving online, as well os tought in the local spoce. As ospects of the teaching progroms are hardened into new Bulletins to be published, which in turn feed bock into subsecuent teoching. published, which in turn feed bock into subsequent teaching, on the some six-month cycle os the Bulletins. His or her duties use of its resources. He or she also proposes reconfiguring course, still the defoult model in contemporary art and design brush, pencil paint type dodge \& burn, mogic wand etc. and workshops, which drow frequently on the Librory's
books and artifacts for immediate exomple ond insight. In other words, the course will aim to build o critical faculty 